\title{
EVALUATE THE ABILITY OF DIETARY ACTIVE YEAST TO ALLEVIATE NEGATIVE EFFECT OF OCHRATOXIN A (OTA) ON NILE TILAPIA (OREOCHROMIS NILOTICUS) FINGERLINGS
}

\author{
A.T. Mansour ${ }^{1}$; Omar, Eglal A. ${ }^{1}$; M.K. Soliman ${ }^{2}$; T.M. Srour ${ }^{1}$ and A.M. Nour ${ }^{3}$ \\ ${ }^{1}$ Department of Fish and Animal Production, Faculty of Agriculture (Saba Basha), Alexandria \\ University, Alexandria, Egypt \\ ${ }^{2}$ Faculty of Veterinary Medicine, Damanhour University, El-Behira, Egypt. \\ ${ }^{3}$ Department of Fish and Animal Production, Faculty of Agriculture (El-Sahtby), Alexandria \\ University, Alexandria, Egypt.
}

(Received 3/2/2016, accepted 22/3/2016)

\section{SUMMARY}

$\mathrm{O}$ chratoxin A (OTA) is one of the most abundant mycotoxins in fish diets and cause a severe loss in fish body weight and suppression of immune responses. The present study was conducted to evaluate the ability of dietary active yeast (Saccharomyces cerevisiae) to alleviate the drastic effect of OTA on Nile tilapia (Oreochromis niloticus) fingerlings (23.39 $\pm 0.16 \mathrm{~g}$ ). Six experimental treatments were applied in 18 circular fiberglass tanks $\left(0.5 \mathrm{~m}^{3}\right.$; three tanks per treatment $)$. The treatments were: control, yeast supplementation $\left(0.5 \mathrm{~g} \mathrm{~kg}^{-1}\right.$ diets), low OTA dose (LOTA; $80 \mu \mathrm{g} \mathrm{kg}^{-1}$ bwt), high OTA dose (HOTA; $160 \mu \mathrm{g} \mathrm{kg}^{-1}$ bwt), LOTA plus yeast and HOTA plus yeast. The OTA doses applied as a single dose on the first day of the experiment by stomach intubation, then the experiment lasted for 8 weeks. All treatments were vaccinated with Aeromonas hydrophila bacterin after one month of OTA treatments. Results indicated that OTA caused a significant reduction in final bwt, weight gain, average daily gain and significant deterioration of feed conversion ratio (FCR) in a dose dependent manner compared to the control group. The survival rate decreased by 10 and $26.67 \%$ with low and high OTA doses, respectively than the control group. WBCs, lymphocytes, phagocytic activity, phagocytic index, total protein, albumin and globulin decreased significantly with both of OTA doses. Antibody titer was reduced significantly with OTA treatments in a dose dependent manner and the significant effect of OTA in high dose appeared after two weeks of vaccination compared to control. The histology of liver and posterior kidney revealed that there was an increase in the incidence and severity of histopathological lesions in a dose dependent manner. However, dietary yeast alone improved significantly growth performance, survival rate, FCR, and stimulated both innate and adaptive immune responses, also, didn't show histological changes in tested organs. The yeast supplementation to OTA treated fish overcomes successfully the drastic effect of OTA on the all previous mentioned parameters. In conclusion, OTA causes interruption of Nile tilapia performance, suppression of innate and adaptive immune response, whereas, active yeast supplementation showed a protective effect of active yeast against the OTA toxicity.

Keywords: Ochratoxin A; yeast; antibody titer; phagocytosis; histopathology; tilapia.

\section{INTRODUCTION}

Mycotoxins are microbial agents which cause food or feed-borne intoxication and are therefore considered as undesirable substances in feed and food (Sweeney and Dobson, 1998). No region of the world escapes the problem of mycotoxins and according to Lawlor and Lynch (2005), mycotoxins are estimated to affect as much as $25 \%$ of the world's crops each year. Mycotoxins cause dramatic economic loss, which appear directly by inducing poor performance and productivity of animals. Indirectly, economic decline consists of chemical analyses costs, quality control and regulatory programs, research and development, extension services, law suits, and the cost of human illnesses. Even during favorable condition, it is likely that millions of dollars are lost as a result of the contamination of crops with mycotoxins (Charmleyet al. 1995).

Ochratoxin is one of the most abundant mycotoxins contaminated fish feed. Ochratoxins produced as secondary metabolites of fungi of two genera: Penicillium and Aspergillus, which include ochratoxin A; ochratoxin B; ochratoxin C; ochratoxin $\alpha$. The most toxic member is ochratoxin A (OTA) (Ringot et al., 2006). Ochratoxin A can be found as a natural contaminant in cereals (wheat, maize, oats, millet, rye, barley and rice), wine-grapes, musts, beer, coffee beans, cocoa, dried wine fruits, spices and nuts (Ringot et al., 2006; El Khoury et al., 2008; Pietri et al., 2012).

Ochratoxin A causes loss in live body weight of O. niloticus and Cyprinus carpio (Farag, 2005), reduction in weight gain and deterioration of FCR of catfish (Manning et al., 2003). Moreover, OTA induced DNA adducts and oxidative stress (Sava et al., 2006). Furthermore, OTA increased incidence and severity of melanomacrophage centers in hepatopancreatic tissue and posterior kidney of catfish fed 


\section{Mansour et al.}

dietary contaminated diet with $2.0 \mathrm{mg}$ OTA $/ \mathrm{kg}$ or above (Manning et al., 2003). In addition, Manning et al. (2005) indicated that juvenile channel catfish fed OTA had greater mortality when challenged with enteric septicemia bacteria (Edwardsiella ictaluri) compared with the control group. Several studies showed the suppressive effect of the OTA on immune system, in the case of innate and adaptive immune response (Verma et al., 2004; Elaroussi et al., 2006; Wang et al., 2009). However, the effect of OTA on Nile tilapia immune system still needs more research.

The role of microorganisms in detoxification of OTA has a lot of concern, via promoting the hydrolysis of OTA to its nontoxic alpha form (OT $\alpha$ ) in the case of ruminant (Sreemannarayana et al., 1988) and nonruminant (Madhyastha et al., 1992). Yeasts on of the most suspicious microorganisms presenting antagonistic effect on the production and facilitate the degradation of OTA (Petersson et al., 1998). Also, heat treated yeast absorbed a significant amount of the OTA (Péteri et al., 2007). Also, Molnar et al. (2004) found that yeast strain of the genus Trichosporon from the hindgut of the termite able to detoxify mycotoxins such as OTA. Besides, fish gastric microorganisms able to transform mycotoxin to nontoxic form in various environmental conditions (Guan et al., 2009).

Yeast reduce the presence of potentially pathogenic bacteria by competitive exclusion and causes intestinal microbial balance of the host organism and confer various beneficial effects include immunostimulation and enhance disease resistance (Gatlin et al., 2006).

Therefore, this experiment was conducted to evaluate the efficacy of dietary active live yeast to ameliorate the drastic effect of OTA on growth performance, blood biochemistry, specific and nonspecific immune response, and histopathology of Nile tilapia (O. niloticus).

\section{MATERIALS AND METHODS}

\section{Experimental fish and diets}

A total number of 270 apparently healthy male Nile tilapia, $O$. niloticus, fingerlings $(23.39 \pm 0.16 \mathrm{~g})$ obtained from the experimental fish farm of Faculty of Agriculture (Saba Basha) Alexandria University was used. Experimental fish were kept for 21 days in circular fiberglass tanks as an acclimatization period at a rate of 50 fish/tank and fed on control diet. 18 circular fiberglass tanks $\left(1 \mathrm{~m}^{3}\right)$, three tanks/treatment each was adjusted to have $0.5 \mathrm{~m}^{3}$ of water. Each tank was stocked with 15 fish. Water temperature was checked daily, and ranged between $25-27^{\circ} \mathrm{C}$. Continuous aeration was maintained in each tank using an electric air pumping compressor. Manual method for removal of excreta was conducted every day before the first feeding by siphoning $10 \%$ of the water volume of the tank and replaced by an equal volume of water.

The experimental diets $32 \%$ crude protein was formulated (Table 1) and fed to the experimental fish two times a day (9.00 AM -14.00 PM) at a rate of 3\% of the actual live fish body weight which adjusted biweekly (6 days a week). The chemical analysis of the diets was performed according to AOAC (1995).

\section{Experimental design}

Six treatments continue for eight weeks were designed as follows: control treatment (free from both OTA and yeast $)$, yeast supplementation $\left(0.5 \mathrm{~g} \mathrm{~kg}^{-1}\right.$ diet; Tonilisat ${ }^{\circledR}, 8 \times 10^{9}$ cells/gram; China way Corporation, Taiwan), low OTA at a dose of $80 \mu \mathrm{g} \mathrm{kg}^{-1}$ bwt (LOTA; Sigma Chemical Company, U.S.A, in powder form), high OTA at a dose of $160 \mu \mathrm{g} \mathrm{kg}^{-1}$ but (HOTA), LOTA supplemented with yeast and HOTA supplemented with yeast. The OTA doses performed by single stomach intubations on day zero of the experiment and to conquer the disadvantage of regurgitation of stomach contents after oral exposure, we hold fish in a vertical position with the head above for 5 minutes after dosing (AbdelWahhab et al., 2005).

\section{Growth performance}

At the termination of the experiment fish were group weight, counted per each replicate in each treatment. Weight gain, average daily gain (ADG), specific growth rate (SGR), survival and feed conversion ratio (FCR) were determined for each group using the following equations:

Weight gain $(\mathrm{g} / \mathrm{fish})=$ final body weight $(\mathrm{g})-$ initial body weight $(\mathrm{g})$

Average daily gain $(\mathrm{ADG} ; \mathrm{g} / \mathrm{fish})=$ Weight gain $(\mathrm{g}) /$ period

Specific growth rate $(\mathrm{SGR}, \% /$ day $)=[($ Ln final weight-Ln initial weight $) /$ period $] \times 100$

Survival $(\%)=($ No. of fish at the end/ No. of fish at the beginning of the experiment $) \times 100$

Food conversion ratio $(\mathrm{FCR})=$ feed intake (dry weight, $\mathrm{g}$ ) / weight gain (wet weight, $\mathrm{g}$ ).

\section{Non specific immune response}

Fifteen fish per treatment were anesthetized with tricaine methanesulphonate MS-222, 70 ppm before injection or blood collection. After anesthetizing fish, the blood samples were collected from the caudal vein into plastic Eppendorf tubes with a 2-ml preheparinised syringe and a 24-gauge needle from five fish of each pooled sample group. 
The blood sample was divided into two portions, the first part used for microscopical determination of white blood cells count (WBCs), differential leucocytes count, phagocytic activity (PA) and phagocytic index (PI). WBCs performed using a Neubauer hemocytometer and Shaw's solutions as dilution fluids, differential leucocytes count performed using blood smears which fixed by ethyl 95\%, then stained with Giemsa and differential count conducted by light microscope following the method of Hesser (1960).

Phagocytes assay was determined according to (Kawahara et al., 1991). Fifty $\mu \mathrm{g}$ Candida albicans culture (previously adjusted to $1 \mathrm{mg}$ C. albicans $100 \mathrm{ml}^{-1}$ saline) was added to $1 \mathrm{ml}$ of heparinzed blood collected from treated and control fish and shaken in water bath at $23-25^{\circ} \mathrm{C}$ for $3-5$ hours. Smears of the blood were fixed by ethyl 95\%, then stained with Giemsa solution. Phagocytosis was estimated by determining the proportion of macrophages, which contained intracellular yeast cells in a random count of 300 phagocytes and expressed as a percentage and called PA. The number of phagocytized organisms was counted in the phagocytic cells and called PI.

The second part of the blood sample was conducted to plasma separation. Blood samples in Eppendorf tubes were centrifuged at $3000 \mathrm{rpm}$ for $10 \mathrm{~min}$ and pipetted the supernatant without disturbing the weight Buffy layer. The collected plasma stored at $-20^{\circ} \mathrm{C}$ until analysis, which include determination of total protein, albumin and globulin, were carried out by using commercial kits produced by Bio-diagnostic Co. Egypt.

\section{Specific immune response}

All fish in two tanks of each group was vaccinated with bacterin after 4 weeks of experiment by intraperitonial injection with formalin killed A. hydrophila $\left(6 \times 10^{8} \mathrm{CFUml}^{-1}\right)$, and after 2 weeks the injected fish received booster dose of bacterin the other tank injected with sterile saline. Blood samples were collected four times every week post injection from the caudal vein after anesthetized of inoculated fish to determine bacterial agglutination titer according to the method described by Badran (1990).

The antibody titer (bacterial agglutination) test was performed in a standard Microtiter plate (U-shaped wells), serial two fold dilutions of plasma were made in sterile saline solution, using a $25 \mu 1$ plasma and 25 $\mu \mathrm{l}$ diluter. A. hydrophila antigen $(25 \mu \mathrm{l})$ was added to the diluted plasma. The suspensions were mixed and incubated overnight in the refrigerator. A positive serological reaction was indicated by antibody titer. Antibody titer was expressed as $\log 2$ of the highest plasma dilution still giving a clear agglutination.

Table (1). Formula and chemical composition (\%) of the experimental diet.

\begin{tabular}{|c|c|}
\hline Ingredient & Basal diets \\
\hline Fish Meal & 14 \\
\hline Soy bean meal & 36 \\
\hline Yellow Corn & 6.5 \\
\hline Lupine & 17.5 \\
\hline Rice particles & 18 \\
\hline Wheat Bran & 4 \\
\hline Corn oil & 2 \\
\hline Vitamins and Minerals Mixture $^{1}$ & 2 \\
\hline \multicolumn{2}{|l|}{ Chemical composition \% } \\
\hline Dry matter $(\mathrm{DM})$ & 95.94 \\
\hline \multicolumn{2}{|l|}{ Nutrient $(\%)$ on dry matter basis } \\
\hline Crud protein $(\mathrm{CP})$ & 32.35 \\
\hline Ether extract & 4.65 \\
\hline Ash & 6.48 \\
\hline Crude fiber & 5.04 \\
\hline Nitrogen free extract (NFE) & 51.58 \\
\hline Gross energy $(\mathrm{kcal} / 100 \mathrm{~g} \mathrm{DM})^{2}$ & 438.33 \\
\hline $\mathrm{P} / \mathrm{E}$ ratio (mg CP: Kcal) & 73.80 \\
\hline \multicolumn{2}{|c|}{ 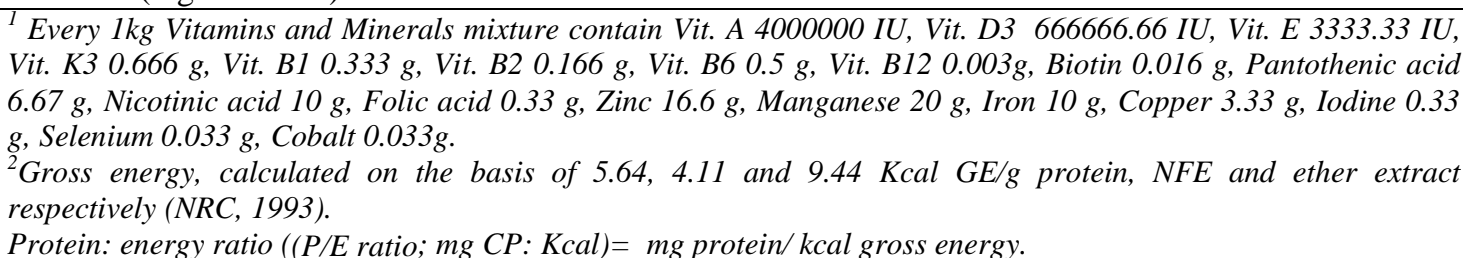 } \\
\hline
\end{tabular}

\section{Histology of hematopiotic organs}

Livers and posterior kidney (main hematopiotic organs in fish) were removed from the fish of the experimental groups at the end of the experiment and rapidly placed in adequate amount of $10 \%$ neutral buffered formalin for at least 24 hours. The fixed specimens were, thereafter, processed through the 
conventional paraffin embedding technique (dehydration through ascending grades of ethanol, clearing in chloroform and finally embedding in melted paraffin wax at $60^{\circ} \mathrm{C}$ ). Paraffin blocks were prepared from which 5 microns thick sections were stained with Hematoxylin and Eosin (H\&E) according to the method described by Culling (1983).

Statistical analysis of data

All data were presented as means \pm stander error. One-way analysis of variance (ANOVA) was used to test for differences across all treatment groups. Duncan (1955) multiple range test was used to determine the significance levels among the means of treatments. Differences were considered significant at $P<0.05$. Statistical analysis of the experimental results was conducted according to SPSS 17.00 (SPSS, Chicago, IL, USA).

\section{RESULTS AND DISCUSSION:-}

\section{Growth performance:}

Growth performance of $O$. niloticus treated with OTA with or without yeast supplementation presented in Table (2). The results indicated that both of OTA doses reduced significantly final body weight (FBW), average daily gain (ADG), body weight gain (BWG) and specific growth rate (SGR) than other treatments. Meanwhile, yeast supplementation to ochratoxicosed fish improved significantly growth performance than OTA treated fish; also yeast alone improved significantly growth than control and other treatments.

Survival rate $(\%)$ decreased by 10 and $26.67 \%$ with low and high OTA doses, respectively, than the control group. Meanwhile, yeast supplementation to fish received low and high OTA treatments improved survival rate by 6.69 and $16.67 \%$, respectively, compared to respect OTA treatments. FCR deteriorated significantly with low and high OTA treatments (41.00 and $40.64 \%$, respectively) compared to the control group. Supplementation with yeast improved significantly FCR than respect OTA treatments by 33.16 and $14.06 \%$, respectively.

The present results are in agreement with the findings of Manning et al. (2003) on channel catfish, they showed that fish exposed to OTA revealed significant reduction in weight gain and survival after eight weeks of treatment. Moreover, Srour (2004) found that exposure of O. niloticus to OTA resulted in a reduction in the growth performance, survival, feed and nutrients utilization of fish in a dose dependent manner. Also, Farag (2005) found that OTA caused losses in FBW and BWG of O. niloticus and $C$. carpio fed on diet contaminated with $7 \mathrm{mg} \mathrm{OTA} \mathrm{kg}^{-1}$ diet.

The depressing effect of OTA on growth performance of treated fish may be attributed to several major mechanisms such as inhibition effect of OTA on protein synthesis (Ringot et al., 2006). As well, OTA causes DNA adduction which enhanced apoptosis; consequently, OTA-induced programmed cell death (Lioi et al., 2004).

Table (2). Final Body weight (FBW), body weight gain (BWG), specific growth rate (SGR), survival and feed conversion ratio (FCR) of OTA treated O. niloticus with or without yeast supplementation.

\begin{tabular}{lllllll}
\hline Treatments & $\begin{array}{l}\text { FBW } \\
\text { (g/fish) }\end{array}$ & $\begin{array}{l}\text { BWG } \\
\text { (g/fish) }\end{array}$ & $\begin{array}{l}\text { ADG } \\
\text { (g/fish/day) }\end{array}$ & $\begin{array}{l}\text { SGR } \\
(\% / \text { day })\end{array}$ & $\begin{array}{l}\text { Survival } \\
(\%)\end{array}$ & FCR \\
\hline Control & $38.62 \pm 0.81^{\mathrm{b}}$ & $15.22 \pm 0.58^{\mathrm{b}}$ & $0.27 \pm 0.01^{\mathrm{b}}$ & $0.89 \pm 0.02^{\mathrm{b}}$ & $100.00 \pm 0.0$ & $2.78 \pm 0.02^{\mathrm{c}}$ \\
Yeast & $43.75 \pm 0.75^{\mathrm{a}}$ & $21.00 \pm 0.50^{\mathrm{a}}$ & $0.38 \pm 0.01^{\mathrm{a}}$ & $1.17 \pm 0.01^{\mathrm{a}}$ & $100.00 \pm 0.0$ & $2.02 \pm 0.09^{\mathrm{d}}$ \\
LOTA & $33.57 \pm 0.03^{\mathrm{cd}}$ & $10.49 \pm 0.48^{\mathrm{cd}}$ & $0.19 \pm 0.01^{\mathrm{cd}}$ & $0.67 \pm 0.04^{\mathrm{cd}}$ & $90.00 \pm 10.0$ & $3.92 \pm 0.10^{\mathrm{a}}$ \\
HOTA & $33.46 \pm 0.45^{\mathrm{d}}$ & $10.09 \pm 0.56^{\mathrm{d}}$ & $0.18 \pm 0.01^{\mathrm{d}}$ & $0.64 \pm 0.03^{\mathrm{d}}$ & $73.33 \pm 0.00$ & $3.91 \pm 0.19^{\mathrm{a}}$ \\
LOTA + & $38.81 \pm 0.13^{\mathrm{b}}$ & $15.46 \pm 0.35^{\mathrm{b}}$ & $0.28 \pm 0.01^{\mathrm{b}}$ & $0.91 \pm 0.02^{\mathrm{b}}$ & $96.69 \pm 3.34$ & $2.62 \pm 0.05^{\mathrm{c}}$ \\
yeast & & & & & & \\
HOTA + & $35.44 \pm 0.06^{\mathrm{c}}$ & $11.99 \pm 0.08^{\mathrm{c}}$ & $0.21 \pm 0.00^{\mathrm{c}}$ & $0.74 \pm 0.00^{\mathrm{c}}$ & $90.00 \pm 10.0$ & $3.36 \pm 0.17^{\mathrm{b}}$ \\
yeast & & & & & & \\
\hline
\end{tabular}

Means $( \pm S E)$ in the same column having different letters are significantly different $(P<0.05)$.

Similarly with the improvement effect of yeast in the present results, Abdel-Tawwab et al. $\left(2008^{\mathrm{a}}\right.$ and $2008^{\mathrm{b}}$ ) found that the optimum growth, feed utilization, and protein turnover of $O$. niloticus were obtained with yeast ( $S$. cerevisiae) supplementation than the control group. Concerning the enhancement of growth performance and nutrient utilization happened upon yeast supplementation, the findings of Lara-Flores et al. (2003) explain the present results where the authors demonstrated that yeast is an appropriate growth-stimulating supplementation in $O$. niloticus practical diet. The better growth performance with yeast supplemented diets may due to improve diet and protein digestibility (De-Schrijver and Ollevier, 2000). 
Moreover, yeast reduces the presence of potentially pathogenic bacteria by competitive exclusion and causes intestinal microbial balance of the host organism (Fuller, 1991). Also, yeast supplementation accelerates digestive system maturation and increases nutrient digestibility (Waché et al., 2006). Furthermore, Buts et al. (1994) reported that yeast may release spermine and spermidine in the digestive tract, which playing a fundamental role in proliferating, fast growth and regenerating tissue (Peulen et al., 2002).

The detoxification effect of yeast on OTA may be related to the ability of yeasts to secrete an enzyme related to carboxypeptidases which convert OTA to OT $\alpha$ (nontoxic form) (Péteri et al., 2007) by the cleavage of the peptide bond between isocoumarin and phenylalanine in OTA moiety (Marquardt, 1996). Since, fish gastric microorganisms able to transform mycotoxins to a nontoxic form in various environmental conditions (Guan et al., 2009). Furthermore, yeast cell wall was an effective adsorbent for OTA (Ringot et al., 2007) which may reduce OTA absorption from the fish gastrointestinal tract and excluded with feces.

\section{Nonspecific immune response}

The effect of OTA with or without yeast on nonspecific immune response as measured through WBCs, differential leucocytes count and phagocytosis (PA and PI) which one of the most important components of the second line of the body's defense against pathogens demonstrated in Table (3) and plasma proteins in Table (4).

White blood cells count, lymphocytes, neutrophils, PA and PI decreased significantly with both of OTA doses than control and yeast supplementation treatments. Monocytes decreased insignificantly than control and yeast supplementation treatments. Meanwhile, Yeast supplementation alone or with ochratoxicosed fish improved successfully the previous parameters. The blood parameter as leucocytes count has diagnostic importance and usually rapidly responded to identical factors such as physicals, chemicals and biological stressors (Mauri et al., 2011). The decrease of PA and PI may due to the destructive effect of OTA on liver and posterior kidney exposed to LOTA and HOTA doses (Fig. 4, 5, 10 and 11). The suppression of PA and PI by OTA may be due to the stress effect of OTA on $O$. niloticus (Montero et al., 2001). Which, OTA lead to increase level of plasma cortisol, consequently, suppress the phagocytosis function (Chen et al., 2002). In the contrary, these findings disagreed with Manning et al. (2003) they reported that white blood cell counts showed insignificant differences among OTA treatments even though catfish fed the highest levels of OTA, where WBCs was substantially greater than that of the control catfish. The disagreements may attribute to the differences in type of the fish in the two experiments.

Table (3). White blood cells (WBCs), differential leucocytes count, phagocytosis activity (PA) and phagocytosis index (PI) of OTA treated $O$. niloticus with or without yeast supplementation.

\begin{tabular}{|c|c|c|c|c|c|c|}
\hline Treatment & $\begin{array}{l}\text { WBCs } \\
\left(\mathrm{x} 10^{3} / \mathrm{ml}\right)\end{array}$ & $\begin{array}{l}\text { Lymphocytes } \\
(\%)\end{array}$ & $\begin{array}{l}\text { Monocytes } \\
(\%)\end{array}$ & $\begin{array}{l}\text { Neutrophils } \\
(\%)\end{array}$ & $\begin{array}{l}\text { PA } \\
(\%)\end{array}$ & $\begin{array}{l}\text { PI } \\
\text { (cells) }\end{array}$ \\
\hline Control & $22.83 \pm 0.89^{\mathrm{a}}$ & $80.75 \pm 1.25^{\mathrm{ab}}$ & $2.00 \pm 0.58$ & $17.25 \pm 1.31^{\mathrm{cd}}$ & $21.13 \pm 0.31^{b}$ & $1.84 \pm 0.04^{b}$ \\
\hline Yeast & $23.01 \pm 0.20^{\mathrm{a}}$ & $82.25 \pm 0.48^{\mathrm{a}}$ & $2.00 \pm 0.41$ & $15.75 \pm 0.63^{\mathrm{d}}$ & $24.00 \pm 0.41^{\mathrm{a}}$ & $2.44 \pm 0.04^{\mathrm{a}}$ \\
\hline LOTA & $18.00 \pm 0.71^{\mathrm{bc}}$ & $78.50 \pm 0.29^{b}$ & $1.00 \pm 0.41$ & $20.50 \pm 0.29^{b}$ & $17.65 \pm 0.28^{\mathrm{d}}$ & $1.68 \pm 0.05^{\mathrm{b}}$ \\
\hline HOTA & $17.10 \pm 0.83^{c}$ & $73.50 \pm 0.65^{c}$ & $1.50 \pm 0.65$ & $25.00 \pm 0.41^{\mathrm{a}}$ & $15.90 \pm 0.16^{\mathrm{e}}$ & $1.45 \pm 0.03^{\mathrm{c}}$ \\
\hline $\begin{array}{l}\text { LOTA + } \\
\text { yeast }\end{array}$ & $19.15 \pm 0.89^{b}$ & $80.25 \pm 0.48^{\mathrm{ab}}$ & $1.75 \pm 0.25$ & $18.00 \pm 0.41^{\mathrm{c}}$ & $19.68 \pm 0.23^{c}$ & $1.82 \pm 0.05^{\mathrm{b}}$ \\
\hline $\begin{array}{l}\text { HOTA + } \\
\text { yeast }\end{array}$ & $18.28 \pm 1.00^{\mathrm{bc}}$ & $79.25 \pm 1.11^{\mathrm{b}}$ & $2.25 \pm 0.75$ & $18.50 \pm 0.65^{b c}$ & $17.53 \pm 0.21^{\mathrm{d}}$ & $1.74 \pm 0.09^{\mathrm{b}}$ \\
\hline
\end{tabular}

Means $( \pm S E)$ in the same column having different letters are significantly different $(P<0.05)$.

The increase of phagocyte activity by addition of yeast supported by the findings of Sakai et al. (2001) who reported that the nucleotides from brewers' yeast RNA were capable of enhancing the phagocytes and oxidative activities of kidney phagocytic cells, serum lysozyme in common carp as well as resistance to A. hydrophila. Also, Marques et al. (2006) baker's yeast and yeast $\beta$-glucans play an essential role in stimulating the immune response. Moreover, Reyes-Becerril et al. (2008) found that oral dietary of live yeast significantly enhanced phagocytic ability in head kidney leucocytes of gilthead seabream. Also, Jeney et al. (1997) observed stimulation of the phagocytic activity in stressed rainbow trout after glucan feeding.

The investigation of hepatic synthetic function examined by determining total protein, albumin and globulin in treated $O$. niloticus summarized in Tables (4). The results indicated that total protein and globulin reduced significantly with both OTA doses than control and yeast supplementation treatment. However, yeast supplementation improved the hypoalbuminemia, hypoproteinemia and globulin level 
in ochratoxicosed fish. The obtained results agreed with the findings of Koynarski et al. (2007) who reported that feeding chicks on an OTA contaminated diet causes decrease of serum total protein. Also, Wang et al. (2009) found a decrease in serum concentrations of total protein, albumin, and globulin in broiler chickens exposed to OTA alone or with T-2 toxin.

The reduction of plasma total protein may be due to liver damage caused by OTA (Fig. 4 and 5) where all plasma protein synthesis usually occurs in the liver except gamma globulins which are produced by lymphocytes. Moreover, this reduction may be interpreted to the inhibitory effect of OTA to protein synthesis (Ringot et al., 2006). Globulin is the building source of antibody where called immunoglobulin (White, 1986). So globulin used as immune indicator and the decrease of its level in the present study with OTA treatments revealed the immunosuppressive effect of OTA. Also, Choudhury et al. (2005) found that dietary yeast RNA (0.4\% ribonucleic acid) significantly increased total protein and globulin of Rohu (Indian carp).

Table (4). Total protein, albumin and globulin in the plasma of OTA treated $O$. niloticus with or without yeast supplementation.

\begin{tabular}{lllll}
\hline Treatment & $\begin{array}{l}\text { Total protein } \\
(\mathrm{g} / \mathrm{dl})\end{array}$ & $\begin{array}{l}\text { Albumin } \\
(\mathrm{g} / \mathrm{dl})\end{array}$ & $\begin{array}{l}\text { Globulin } \\
(\mathrm{g} / \mathrm{dl})\end{array}$ & $\begin{array}{l}\text { A/G ratio } \\
(\%)\end{array}$ \\
\hline Control & $4.85 \pm 0.08^{\mathrm{a}}$ & $2.97 \pm 0.05$ & $1.88 \pm 0.08^{\mathrm{ab}}$ & $1.59 \pm 0.09^{\mathrm{cd}}$ \\
Yeast & $4.88 \pm 0.13^{\mathrm{a}}$ & $2.70 \pm 0.13$ & $2.18 \pm 0.09^{\mathrm{a}}$ & $1.25 \pm 0.09^{\mathrm{d}}$ \\
LOTA & $4.00 \pm 0.12^{\mathrm{b}}$ & $2.76 \pm 0.18$ & $1.24 \pm 0.12^{\mathrm{c}}$ & $2.35 \pm 0.39^{\mathrm{abc}}$ \\
HOTA & $3.39 \pm 0.19^{\mathrm{c}}$ & $2.53 \pm 0.17$ & $0.87 \pm 0.07^{\mathrm{d}}$ & $2.97 \pm 0.29^{\mathrm{a}}$ \\
LOTA + yeast & $4.52 \pm 0.20^{\mathrm{a}}$ & $3.17 \pm 0.19$ & $1.35 \pm 0.12^{\mathrm{c}}$ & $2.41 \pm 0.26^{\mathrm{ab}}$ \\
HOTA + yeast & $4.62 \pm 0.17^{\mathrm{a}}$ & $2.87 \pm 0.08$ & $1.75 \pm 0.21^{\mathrm{b}}$ & $1.71 \pm 0.22^{\mathrm{bcd}}$ \\
\hline
\end{tabular}

Means $( \pm S E)$ in the same column having different letters are significantly different $(P<0.05)$.

\section{Specific immune response:}

The periodic examination of antibody titer of $O$. niloticus vaccinated with A. hydrphila and treated with OTA with or without yeast presented in Fig. 1. The results indicated that the significant differences observed in the second week after vaccination and continued in the next weeks, where antibody titer significantly reduced with LOTA and HOTA doses than control and yeast supplemented treatment, whereas, the yeast supplementation succeeds to alleviate the suppressive effect of OTA. These results agreed with the findings of Verma et al. (2004) who found a significant decrease in haemagglutination titers in chicks given $4 \mathrm{mg}$ OTA kg${ }^{-1}$ diet. Furthermore, Elaroussi et al. (2006) found that a decrease in humoral immune response and cell-mediated immunity was found in broiler fed OTA in the diet.

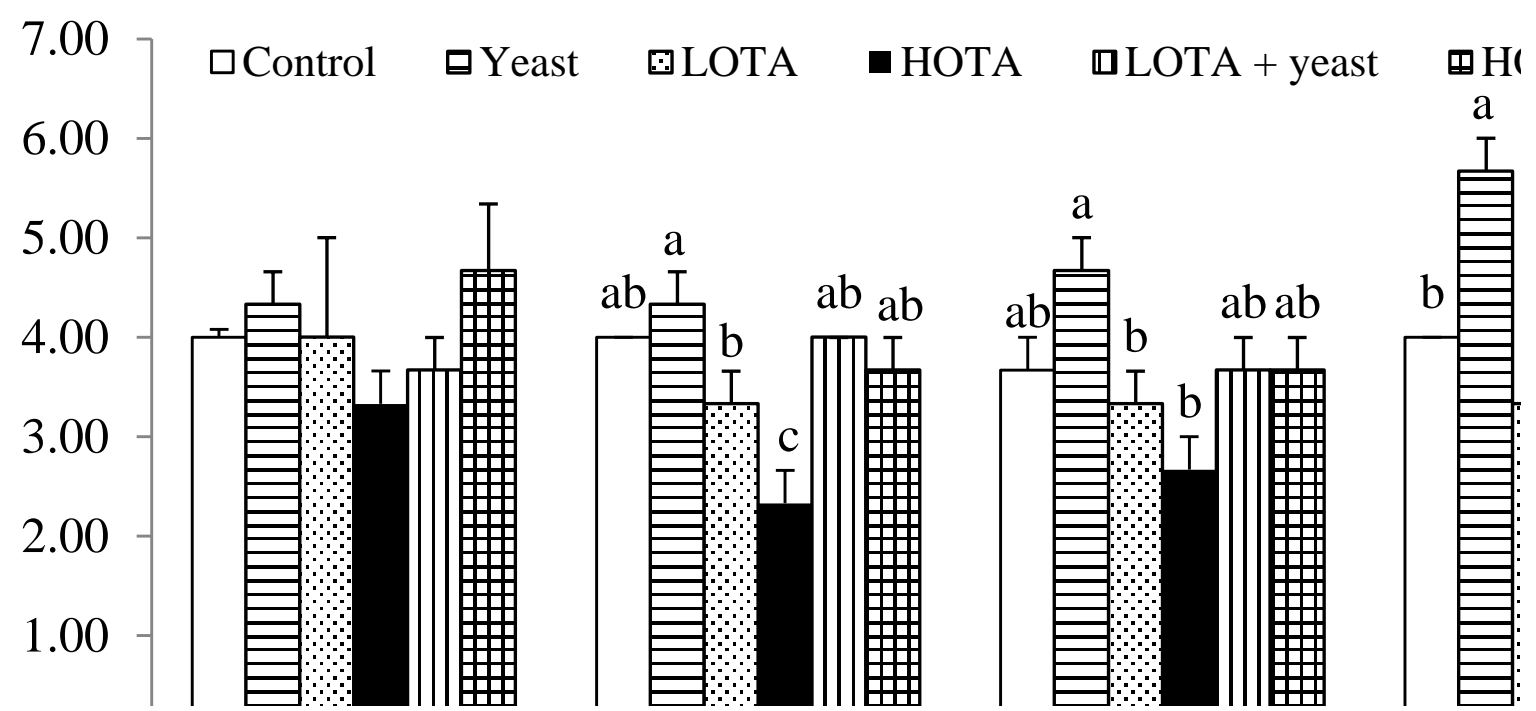

Fig. (1). Bacterial agglutination titer in the plasma of OTA treated $O$. niloticus with or without yeast supplementation, post vaccinated with $A$. hydrphila.

Regarding to the overcome effect of yeast supplementation to OTA on antibody titer. Yoshida et al. (1995) showed that $S$. cerevisiae was a source of nucleic acids and $\beta$-1, 3-glucans which have been recognized to effectively enhance immune functions of African catfish. Also, Anderson and Siwicki (1995) reported that Baker's yeast, $S$. cerevisiae, contains various immunostimulating compounds such 
as $\beta$-glucans, nucleic acids and mannan oligosaccharides. Moreover, glucan treatment in fish enhanced the expression of interleukin 1 and complement activity (Engstad et al., 1992). Yeast accelerated the specific immune response in catfish and Atlantic salmon against vaccines for E. ictaluri and $A$. salmonicida (Baulny et al., 1996). In the same trend Abdel-Tawwab et al. $\left(2008^{\mathrm{a}}\right)$ found that the bacterial count after incubation with fish sera decreased significantly with the increase of yeast level in the diets.

The increasing of immune response with yeast treatment in the present study may be attributed to the presence of yeast $\beta$-glucan. Whereas, $\beta$ - glucans are responsible for a multitude of activities which protect and enhance the immune system, and provide optimum resistance to any possible health assailants due to its ability to bind directly with macrophages and other white blood cells (neutrophils and natural killer (NK) cells) and to activate them (Gantner et al., 2003; Herre et al., 2004). Macrophage cells are one of the principal cell types involved in natural immunity. When $\beta$-glucan receptors are engaged by $\beta$-glucans, all immune functions are improved, including phagocytosis, release of certain cytokines (intercellular hormones) IL-1, IL-6, GM-CSF, interferons, and the processing of antigens. These cytokines stimulates formation of new white blood cells, thus providing immunity to $\beta$ glucan binding receptors present in all vertebrates ranging from fish to human. Fishes have both specific and non-specific defense mechanism. The activated phagocytic cells and WBC (B and T -cells) produce cytokines and antibodies, respectively and enhance the efficacy of vaccines (Raa, 2000).

Histology of hematopiotic organs:

The histological examination of liver and posterior kidney in the control group showed normal histological structure of both liver and posterior kidney ( 2 and 8 ). Moreover, yeast supplementation alone increases glycogen content in liver (Fig. 3) and maintain the normal structure of the posterior kidney (Fig. 9). However, the histological sections of liver of OTA treated fish (Fig. 4 and 5) revealed an incidence of congestion of hepatic sinusoids, hydropic degeneration, fatty changes, activation of melanomacrophage centers (MMCs) and destruction of normal hepatic architecture, the severity of liver lesions increased with OTA increase in a dose dependent manner. Furthermore, posterior kidney in ochratoxicosed fish (Fig. 10 and 11) showed acute cellular swelling, tubular necrosis and activation MMCS especially with HOTA dose. The yeast supplementation of OTA treated fish diets may counteract the destructive effect of ochratoxin in the affected organs (hepatopancreas and posterior kidney) especially at the LOTA dose (Fig. 6, 7, 12 and 13). These results agreed with Doster et al. (1974) who described histopathological damage caused by OTA in trout liver and kidney. Similar results obtained by Manning et al. (2003) on catfish fed dietary concentrations of 2.00 to $8.00 \mathrm{mg}$ $\mathrm{OTA} / \mathrm{kg}$, which revealed increased incidence and activation of MMCs centers in hepatopancreatic tissue and posterior kidney.

The melanomacrophage centers described by Ferguson (1995) as repositories of the end product of cellular breakdown. The circulating macrophages replete with particulate matter home selectively on the melanomacrophage centers, hence the activation of the MMCs considered as indicative on the degree of the tissue damage (Roberts, 2001). The deterioration in hematopiotic organ caused by OTA in the present study may reflect the immunosuppressive effect of OTA on fish. Meanwhile, dietary live yeast thrives to overcome these negative effects of OTA on hematopiotic organs. The effect of OTA on the animal organs includes complex mechanisms of action as an evocation of oxidative stress, bioenergetics compromise, inhibition of protein synthesis, production of DNA single-strand breaks and formation of OTA-DNA adducts (Sava et al., 2006). 


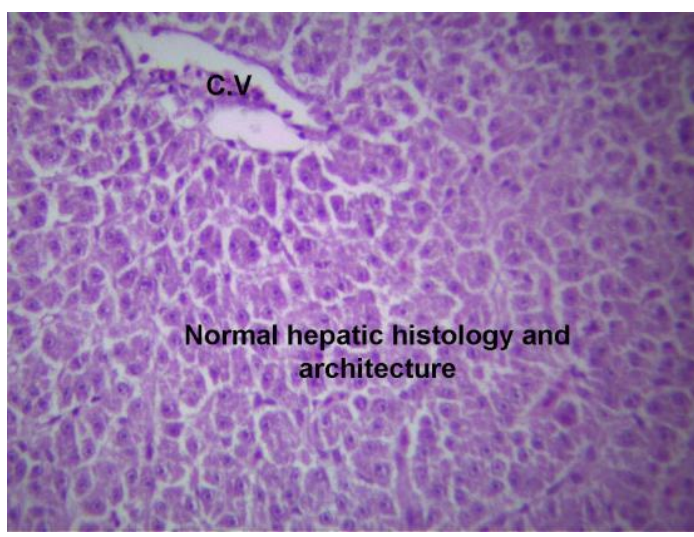

Fig. (2). Liver of normal $O$. niloticus (control) showing normal hepatic architecture and histology. (H\&E; X 160)

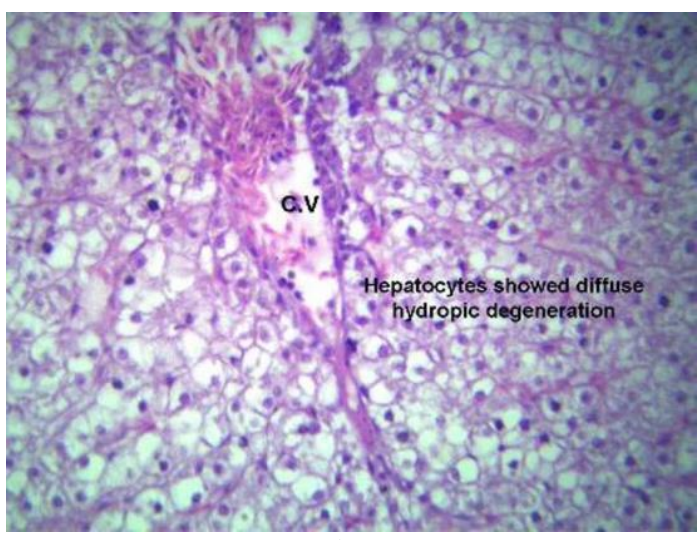

Fig. (4). Liver of $O$. niloticus exposed to LOTA dose, showing diffuse hydropic degeneration of hepatic cells. (H\&E; X 250)

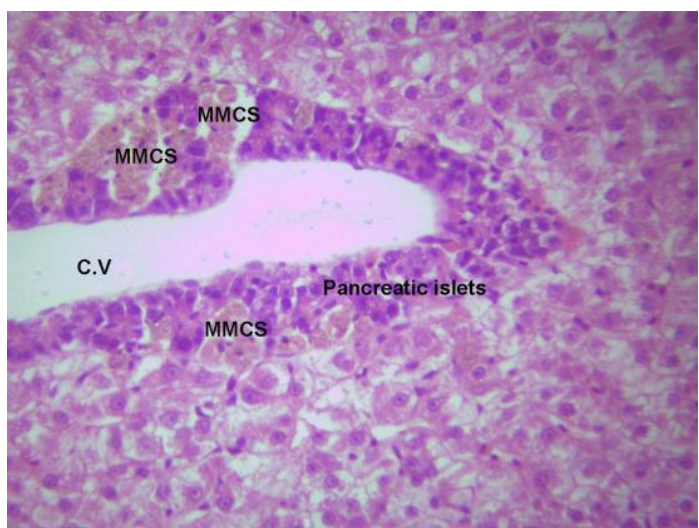

Fig. (6). Liver of $O$. niloticus exposed to LOTA dose, showing mild infiltration of MMCS in pancreatic islets. (H\&E; $X$ 250)

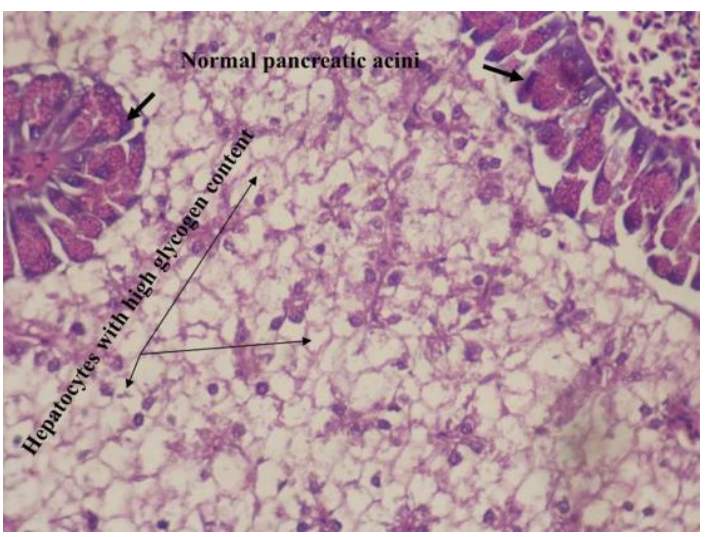

Fig. (3). Liver of $O$. niloticus fed diet supplemented with yeast, showing normal hepatocytes with high glycogen content and normal pancreatic acini. (H\&E; X 250)

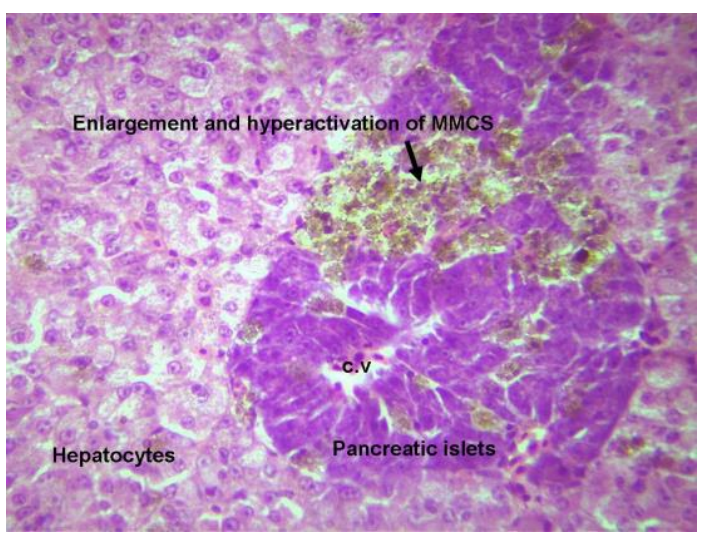

Fig. (5). Liver of $O$. niloticus exposed to HOTA dose, showing severe infiltration of MMCS in pancreatic islets $(H \& E$; $X$ 160).

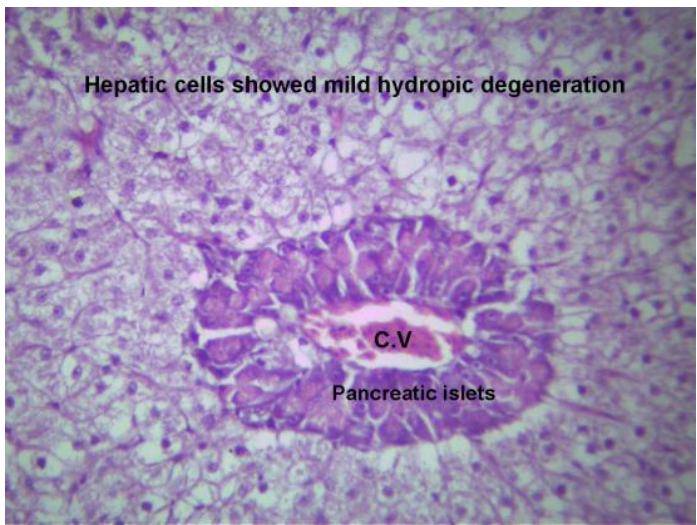

Fig. (7). Liver of $O$. niloticus exposed to HOTA dose plus yeast, showing mild hydropic degeneration of the hepatic cells $(\mathrm{H} \& \mathrm{E}$; X 160). 


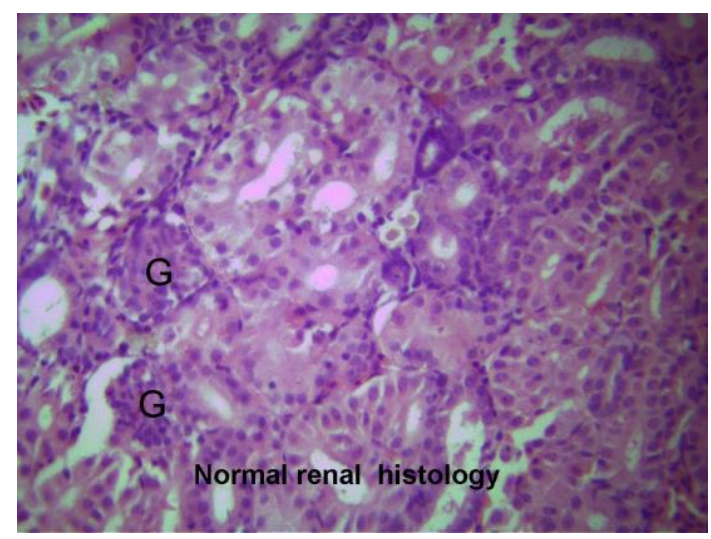

Fig. (8). Posterior kidney of normal $\boldsymbol{O}$. niloticus (control), showing normal renal histology. (H\&E; X 160)

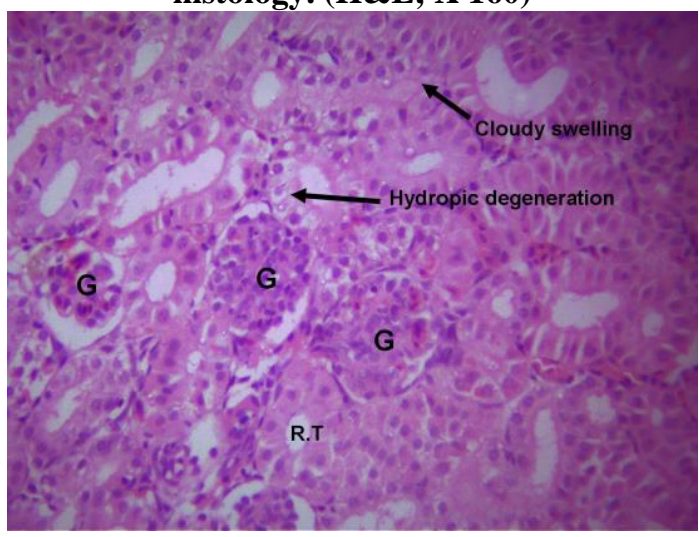

Fig. (10). Posterior kidney of $O$. niloticus exposed to LOTA dose, showing mild acute cellular swelling. (H\&E; X 250)

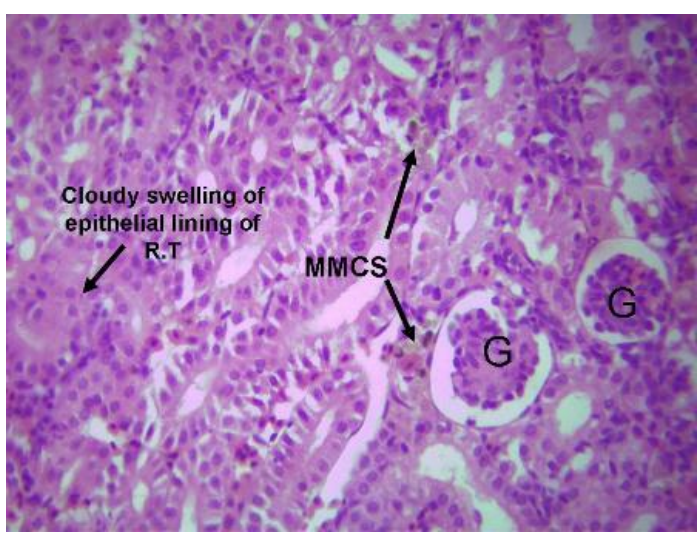

Fig. (12). Posterior kidney of $\boldsymbol{O}$. niloticus exposed to LOTA dose plus whey, showing acute cellular swelling of the tubular epithelial lining beside mild MMCS infiltration within the renal parenchyma. (H\&E; X 250)

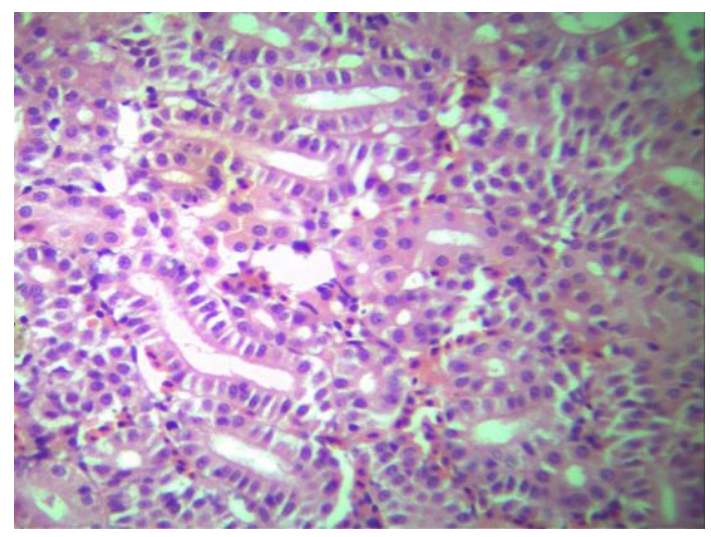

Fig. (9). Posterior kidney of $\boldsymbol{O}$. niloticus fed diet supplemented with yeast, showed normal renal histology. (H\&E; X 160)

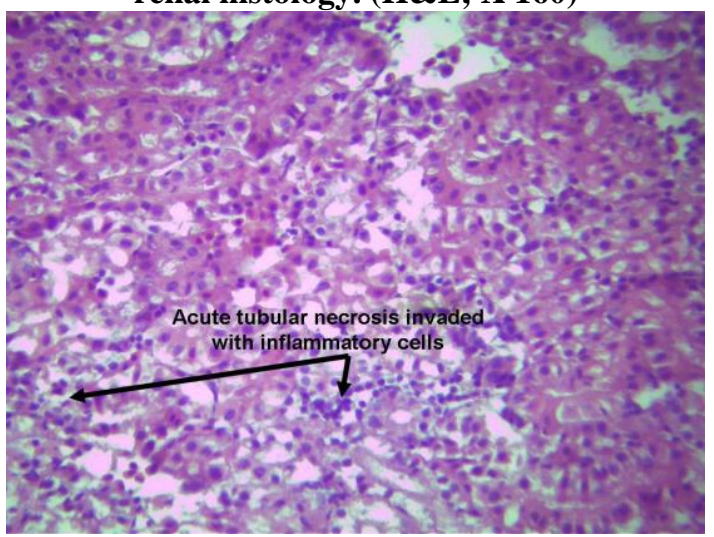

Fig. (11). Posterior kidney of $\boldsymbol{O}$. niloticus exposed to HOTA dose, showing acute tubular necrosis invaded with inflammatory cells (H\&E; X 160).

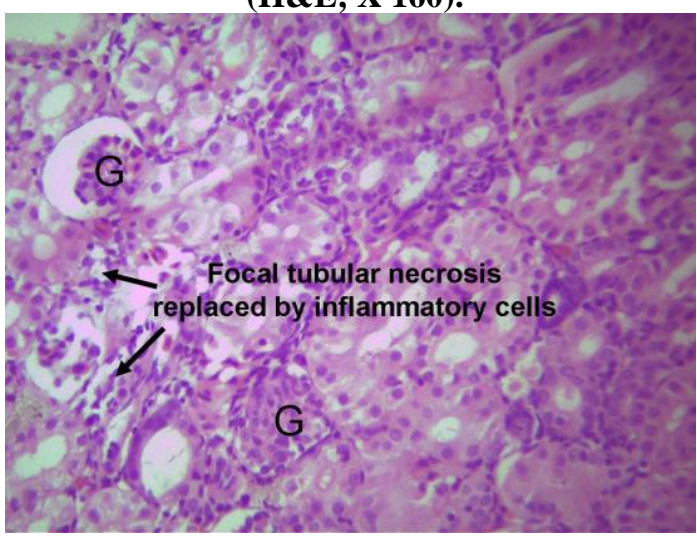

Fig. (13). Posterior kidney of $O$. niloticus exposed to HOTA dose plus whey, showing focal tubular necrosis replaced by inflammatory cells. (H\&E; X 160)

\section{CONCLUSION}

OTA caused reduction of growth performance, survival rate, and deterioration of FCR. Also, OTA showed suppression of immune systems and destruction of liver and posterior kidney of treated fish. Meanwhile, active live yeast showed successful trial in alleviating the negative effects of OTA in Nile tilapia (O. niloticus). 


\section{ACKNOWLEDGEMENTS}

The authors acknowledge the Faculty of Agriculture (Saba Basha), Alexandria University, Egypt for funding this study. Also, we would like to thank Prof. Dr. Mahmoud S. El-Neweshy, Department of Pathology, Faculty of Veterinary Medicine, Alexandria University, Egypt for performing and interpreting the histological investigation of the study.

\section{REFERENCES}

Abdel-Tawwab, M., Abdel-Rahman, A.M. and Ismael. N.E. $\left(2008^{\mathrm{a}}\right)$. Evaluation of commercial live bakers' yeast, Saccharomyces cerevisiae as a growth and immunity promoter for fry Nile tilapia, O. niloticus (L.) challenged in situ with Aeromonas hydrophila. Aquacult., 280: 185-189.

Abdel-Tawwab, M., Mousa, M.A. and Mohammed, M.A. $\left(2008^{\mathrm{b}}\right)$. Effect of yeast supplementation on the growth performance and resistance of Galilee tilapia Sarotherodon galilaeus (L.) to environmental copper toxicity. $8^{\text {th }}$ international symposium on tilapia in aquaculture, 459-474.

Abdel-Wahhab, M.A., Hassan, A.M., Aly, S.E. and Mahrous, K.F. (2005). Adsorption of sterigmatocystin by montmorillonite and inhibition of its genotoxicity in the Nile tilapia (Oreochromis niloticus). Mut. Res., 582: 20-27.

Anderson, D.P. and Siwicki, A.K. (1995). Basic haematology and serology for fish health programs. In: Diseases in Asian aquaculture II. M. Shariff, J. R. Arthur and R. P. Subasinghe (Eds). Fish Health Section, Asian Fisheries Society, Manila, Philippines, pp. 185-202.

AOAC. (1995). Official methods of analysis, $16^{\text {th }}$ edition, Arlington, VA, USA.

Badran, A.F. (1990). The role of adjuvants in the immune response of the fish. Zagazig Vet. Med. J. 18 : 126-136.

Baulny, M.O., Quentel, C., Fournier, V., Lamour, F. and Gouvello, R.L. (1996). Effect of long-term oral administration of B glucan as an immunostimulant or an adjuvant on some non-specific parameters of the immune response of turbot Scophthalmus maximus. Dis. Aquat. Organ., 26: 139147.

Buts, J.P., Keser, N. and Raedemaeker, L. (1994). Saccharomyces boulardii enhance rat intestinal enzyme expression by endoluminal release of polyamines. Pediatric Res., 36: 522-527.

Charmley, L.L., Trenholm, H.L., Prelusky, D.B. and Rosenberg, A. (1995). Economic losses and decontamination. Natural Toxins, 3: 199-203.

Chen, W-H., Sun, L-T., Tsai, C-L., Song, Y-L. and Chang, C-F. (2002). Cold-stress induced the modulation of catecholamines, cortisol, immunoglobulin $\mathrm{M}$, and leukocyte phagocytosis in Tilapia. General and Comparative Endocrinology 126: 90-100.

Choudhury, D., Pal, A.K., Sahu, N.P., Kumar, S., Das, S.S. and Mukherjee, S.C. (2005). Dietary yeast RNA supplementation reduces mortality by Aeromonas hydrophila in rohu (Labeo rohita L.) juveniles. Fish Shellfish Immun., 19 281-291.

Culling, C.F. (1983). Handbook of histopathologic and histochemical staining. $3^{\text {rd }}$ Ed., Buterworth, London.

De-Schrijver, R. and Ollevier, F. (2000). Protein digestion in juvenile turbot (Scophthalmus maximus) and effects of dietary administration of Vibrio proteolyticus. Aquacult., 186: 107-167.

Doster, R.C., Sinnhuber, R.O. and Pawlowski, N.E. (1974). Acute intraperitoneal toxicity of ochratoxin $\mathrm{A}$ and B derivatives in rainbow trout (Salmo gairdneri). Food Cosmet. Toxicol., 12: 499-505.

Duncan, D.B., (1955). Multible range and multible F test. Biometric, 11: 1- 42.

El Khoury, A., Rizk, T., Lteif, R., Azouri, H., Delia, M.L., and Lebrihi, A. (2008). Fungal contamination and Aflatoxin B1 and Ochratoxin A in Lebanese wine-grapes and musts. Food and Chemical Toxicology, 46: 2244-2250.

Elaroussi, M.A., Mohamed, F.R., El Barkouky, E.M., Atta, A.M., Abdou, A.M. and Hatab. M.H. (2006). Experimental ochratoxicosis in broiler chickens. Avian Pathol., 35: 263-269.

Engstad, R.E., Robertsen, B. and Frivold, E. (1992). Yeast glucan induces increase in activity of lysozyme and complemente mediated haemolytic activity in Atlantic salmon blood. Fish Shellfish Immun., 2: 287-297.

Farag, M.E. (2005). plasma protein profile in Nile tilapia Oreochromis niloticus and common carp Cyprinus carpio exposed to ochratoxin A and treated with some antitoxins. Eg. J. Agric. Res., 83: 1397-1416.

Ferguson, H.W. (1995). Systemic pathology of fish. Lowa state University. Press. Ames, IA.

Fuller, R. (1991). Probiotics in human medicine. Gut, 32, 439-442. PMC: 1379087 
Gantner, B.N., Simmons, R.M., Canavera, S.J., Akira, S. and Underhill, D.M. (2003). Collaborative induction of inflammatory responses by dectin-1 and toll-like receptor 2. J. Exp. Med., 197: 11071117.

Gatlin, D.M., Li, P., Wang, X., Burr, G.S., Castille, F. and Lawrence, A.L. (2006). Potencial application of prebiotics in aquaculture. En: Editores: L. Elizabeth Cruz Suarez, Denis Ricque Marie, Mireya Tapia Salazar, Martha G. Neito Lopez, David A. Villarreal Cavazos, Ana C. Puello Cruzy Armando Garcia Ortega. Avances en Nutricion Acuicola VIII. VIII Simposium International de Nutricion Acuicola. 15-17 noviembre. Universidad Autonoma de Nuevo Leon, Monterrey, Nuevo Leon, Mexico. ISBN 970-694-333-5.

Guan, S., He, J., Young, J.C., Zhu, H., Li, X., Ji, C. and Zhou, T. (2009). Transformation of trichothecene mycotoxins by microorganisms from fish digesta. Aquaculture, 290: 290-295.

Herre, J., Gordon, S., Brown, G.D. (2004). Dectin-1 and its role in the recognition of beta-glucans by macrophages. Mol. Immunol., 40: 869-876.

Hesser, E.F. (1960). Methods for Routine Fish Haematology. Progressive Fish Culturist, 22: 164-171.

Jeney, G., Galeotti, M., Volpatti, D., Jeney, Z. and Anderson, D.P. (1997). Prevention of stress in rainbow trout (Oncorhynchus mykiss) fed diets containing different doses of glucan. Aquacult., $154,1-15$.

Kawahara, E., Ueda, T. Nomura, S. (1991). In vitro phagocytic activity of white-spotted shark cells after injection with Aermonas salmonicida extracellular products. Gyobyo Kenkyu, Japan, 26: 213-214.

Koynarski, V., Stoev, S., Grozeva, N., Mirtcheva, T., Daskalov, H., Mitev, J. and Mantle, P. (2007). Experimental coccidiosis provoked by Eimeria acervulina in chicks simultaneously fed on ochratoxin A contaminated diet. Res. Vet. Sci., 82: 225-231.

Lara-Flores, M., Olvera-Novoa, M.A., Guzma'n-Me'ndez, B.E. and Lo'pez-Madrid, W. (2003). Use of the bacteria Streptococcus faecium and Lactobacillus acidophilus, and the yeast Saccharomyces cerevisiae as growth promoters in Nile tilapia (O. niloticus). Aquacult., 216: 193-201.

Lawlor, P.G. and Lynch, P.B. (2005). Mycotoxin management. African Farming and Food Processing, 46: 12-13.

Lioi, M.B., Santoro, A., Barbieri, R., Salzano, S. and Ursini, M.V. (2004). Ochratoxin A and zearalenone: a comparative study on genotoxic effects and cell death induced in bovine lymphocytes. Mutation Res., 557: 19-27.

Madhyastha, M.S., Marquardt, R.R. and Frohlich, A.A. (1992). Hydrolysis of ochratoxin A by the microbial activity of digesta in the gastrointestinal tract. Arch. Environ. Contam. Toxicol., 23: 468-472.

Manning, B.B., Terhune, J.S., Li, M.H., Robinson, E.H., Wise, D.J. and Rottinghau, G.E. (2005). Exposure to Feedborne Mycotoxins T-2 Toxin or Ochratoxin A Causes Increased Mortality of Channel Catfish Challenged with Edwardsiella ictaluri. Journal of Aquatic Animal Health. 17: 147-152.

Manning, B.B., Ulloa, R.M., Li, M.H., Robinson, E.H. and Rottinghaus, G.E. (2003). Ochratoxin A fed to channel catfish (Ictalurus punctatus) causes reduced growth and lesions of hepatopancreatic tissue. Aquacult., 219: 739-750.

Marquardt, R.R. (1996). Effects of molds and their toxins on livestock performance: a western Canadian perspective. Anim. feed Sci. Technol., 70: 3968-3988.

Marques, A., Dhont, J., Sorgeloos, P. and Bossier, P. (2006). Immunostimulatory nature of $\beta$-glucans and baker's yeast in gnotobiotic artemia challenge tests. Fish \& Shellfish Immunol., 20: 682-692.

Mauri I., Romeo A., Acerete L., Mackenzie S., Roher N., Callol A., Cano I., Alvarez, M.C. and Tort, L. (2011). Changes in complement responses in Gilthead seabream (Sparus aurata) and European seabass (Dicentrarchus labrax) under crowding stress, plus viral and bacterial challenges. Fish Shellfish Immunol., 30: 182-188.

Molnar, O., Schatzmayr, G., Fuchs, E. and Prillinger, H. (2004). Trichosporon mycotoxinivorans sp nov., A New Yeast Species Useful in Biological Detoxification of Various Mycotoxins. Systematic and Applied Microbiology, 27: 661-671.

Montero, D., Tort, L., Robaina, L., Vergara J.M. and Izquierdo M.S. (2001). Low vitamin E in diet reduces stress resistance of gilthead seabream (Sparus aurata) juveniles. Fish Shellfish Immunol. 11: 473-490.

NRC., (1993). Nutrient requirements of fish. National Academy Press. Washington DC.

Péteri, Z., Téren, J., Vágvölgyi, C. and Varga, J. (2007). Ochratoxin degradation and adsorption caused by astaxanthin-producing yeasts. Food microbiology, 24: 205-210. 


\section{Mansour et al.}

Petersson, S., Hansen, M.W., Axberg, K., Hult, K. and Schnurer, J. (1998). Ochratoxin A accumulation in cultures of Penicillium verrucosum with the antagonistic yeast Pichia anomala and Saccharomyces cerevisiae. Mycol. Res., 102: 1003-1008.

Peulen, O., Deloyer, P. and Dandrifosse, G. (2002). Maturation of intestinal digestive and immune systems by food polyamines. PP.145-167 In: Zabielski, R., Gregory, P.C., Westrom, B. (Eds.), Biology of the intestine in growing animal, Vol. 1., Elsevier, Amesterdam, The Netherlands.

Pietri, A., Rastelli, S., Mulazzi, A., and Bertuzzi, T. (2012). Aflatoxins and ochratoxin A in dried chestnuts and chestnut flour produced in Italy. Food Control, 25: 601-606.

Raa, J. (2000). The use of immune-stimulants in fish and shellfish feeds. In: (Cruz-Suarez LE, RicqueMarie D, Tapia-Salazar M, Olvera-Novoa MA, Civera-Cerecedo R eds) Advance en Nutricion Acuicola V. Memorias del V Simposium Internacional de Nutrcion Acouicola. Merida, Yucatan, pp 47-56.

Reyes-Becerril, M., Salinas, I., Cuesta, A., Meseguer, J., Tovar-Ramirez, D., Ascencio-Valle, F. and Esteban, M.A. (2008). Oral delivery of live yeast Debaryomyces hansenii modulates the main innate immune parameters and the expression of immune-relevant genes in the gilthead seabream (Sparus aurata L.). Fish \& Shellfish Immunol., 25:731-739.

Ringot D., Chango, A., Schneider, Y. and Larondelle, Y. (2006). Toxicokinetics and toxicodynamics of ochratoxin A, an update. Chem. Biol. Interact., 159: 18-46.

Ringot, D., Lerzy, B., Chaplain, K., Bonhoure, J., Auclair, E. and Larondelle Y. (2007). In vitro biosorption of ochratoxin A on the yeast industry by-products: Comparison of isotherm models. Bioresource Technol., 98: 1812-1821.

Roberts, R.J. (2001). Fish pathology. Third edition. Harcourt publishers limited (2001).

Sakai, M., Taniguchi, K., Mamoto, K., Ogawa, H. and Tabata, M. (2001). Immunostimulant effects of nucleotide isolated from yeast RNA on carp, Cyprinus carpio L. J. Fish Dis., 24: 433-438.

Sava, V., Reunova, O., Velasquez, A., Harbison, R. and Sanchez-Ramos, J. (2006). Acute neurotoxic effects of the fungal metabolite ochratoxin-A. Neurotoxicology, 27: 82-92.

Sreemannarayana, O., Frohlich, A.A., Vitti, T.G., Marquardt R.R. and Abramson, D. (1988). Studies of the tolerence and disposition of ochratoxin A in young calves. J. Anim. Sci., 88: 1703-1711.

Srour, T.M. (2004). Effect of Ochratoxin-A with or with out Biogen ${ }^{\circledR}$ on Growth Performance, Feed Utilization and Carcass Composition of Nile Tilapia (Oreochromis niloticus) Fingerlings. J. Agric. Sci., Mans. Unive., 29: 51-61.

Sweeney, M.J. and Dobson. A.D.W. (1998). Review: Mycotoxin production by Aspergillus, Fusarium and Penicillium species. International Journal of Food Microbiology, 43: 141-158.

Verma, J., Johre, T.S., Swain, B.K. and Ameena, S. (2004). Effect of graded levels of aflatoxin, ochratoxin and their combinations on the performance and immune response of broilers. British. Poult. Sci., 45: 512- 518.

Waché, Y., Auffray, F., Gatesoupe, F.J., Zambonino, J., Gayet, V., Labbé, L. and Quentel, C. (2006). Cross effects of the strain of dietary Saccharomyces cerevisiae and rearing conditions on the onset of intestinal microbiota and digestive enzymes in rainbow trout, Onchorhynchus mykiss, fry. Aquacult., 258: 470- 478.

Wang, G.H., Xue, C.Y., Chen, F., Ma, Y.L., Zhang, X.B., Bi, Y.Z. and Cao, Y.C. (2009). Effects of combinations of ochratoxin $\mathrm{A}$ and $\mathrm{T}-2$ toxin on immune function of yellow-feathered broiler chickens. Poult. Sci., 88: 504-510.

White, D.G. (1986). Evaluation of a rapid, specific test for detecting colostral IgG in the neonatal calf. Vet. Record, 118: 68-70.

Yoshida, T., Kruger, R. and Inglis., V. (1995). Augmentation of non-specific protection in African catfish, Clarias gariepinus (Burchell) by the long-term oral administration of immunostimulants. J. Fish Dis., 18: 195-198. 
تقييم قدرة الخميرة الذذائية النشطة لتخفيف الأثار السلبية للأوكراتوكسين أ علي إصبعيات أسماك البلطي النيلي

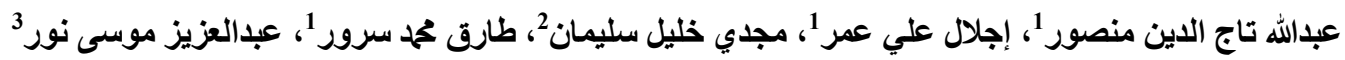

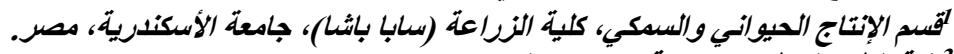

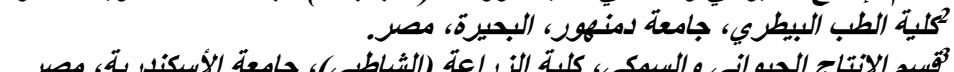

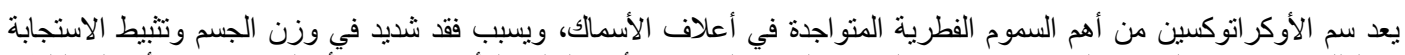

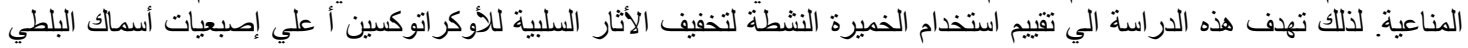

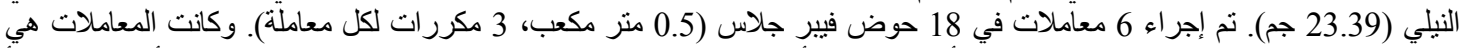

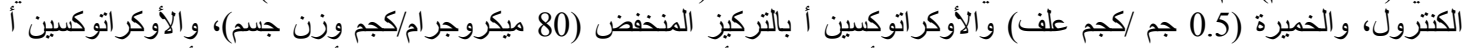

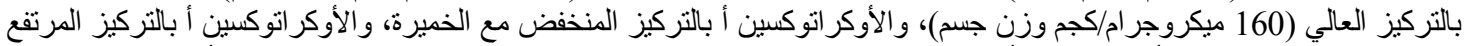

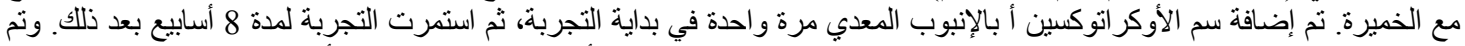

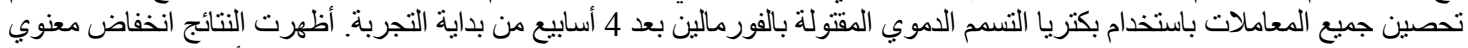

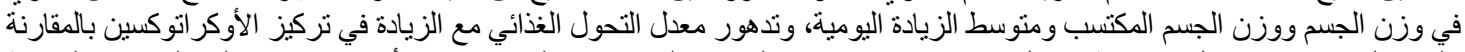

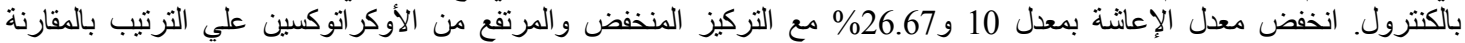

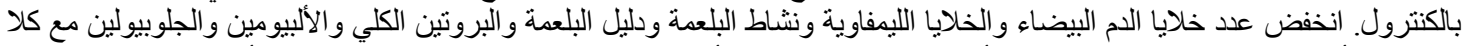

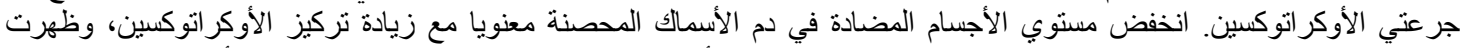

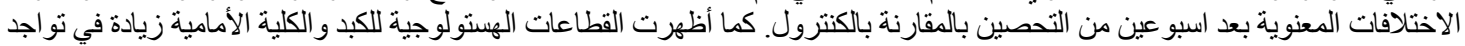

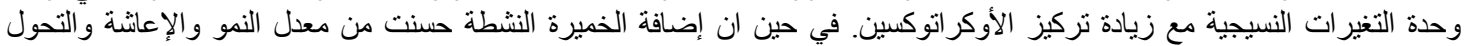

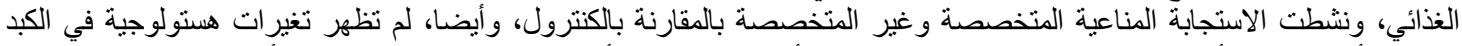

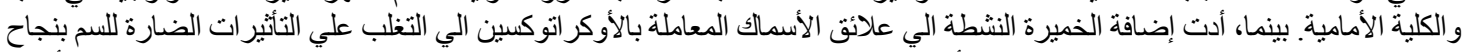

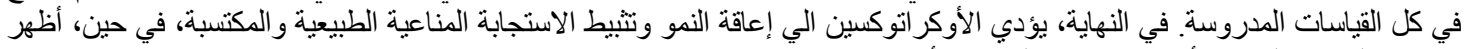
استخدام الخميرة النثطة تأثئير وقائي ضدائد التسمم بالأوكر اتوكسين.

الكلمات الدالة: الأوكراتوكسين أ، الذمبرة، الأجسام المضادة، البلعمة، التغيرات الهستولوجية، البلطي النيلي. 